\title{
CAUSE-EFFECT RELATIONSHIP BETWEEN AIR QUALITY AND PUBLIC HEALTH IN THE CITY OF NOVI SAD BASED ON THE DPSEEA MODEL
}

\author{
Emina S. Kričković \\ University of Belgrade, Faculty of Geography, \\ Belgrade, Republic of Serbia, \\ e-mail: memina1989@gmail.com, \\ ORCID ID: Dhttps://orcid.org/0000-0002-0737-5636
}

DOI: 10.5937/vojtehg69-29301; https://doi.org/10.5937/vojtehg69-29301

FIELD: Geoscience, Environmental protection ARTICLE TYPE: Original scientific paper

\begin{abstract}
:
Introduction/purpose: The research subject in this article is the status of the air quality in the city of Novi Sad and its impact on the health of the population. The relation between these two points will be presented using the DPSEEA model. The research aim of this article is to apply proper measures in order to mitigate negative effects on human health, based on scientific knowledge related to air quality influence on the health of the Novi Sad population. The basic hypothesis of this research implies that air quality affects Novi Sad's population health.

Methods: The following methods were used in this article: modeling, analysis-synthesis, statistic method, classification method, combining method, geographic-ecological method, method of geographic-medical description, method of the medical geography forecast as well as cartographic method.

Results: Based on the DPSEEA model and the example of the air pollution in the city of Novi Sad, the following was identified: air pollution driving forces, pressures, state of the air quality, population exposure to air pollution, effects on human health as well as measures and actions that should be conducted. The mentioned model was also used to present the relationship between these segments.

Conclusion: The given model deals with a wide spectrum of potential forces (harmful effects) and necessary community actions, bringing together professionals, people in the field and those from laboratories as
\end{abstract}

ACKNOWLEDGMENT: The work of the author is supported by the Ministry of Education, Science and Technological Development of the Republic of Serbia, Project 176088. 
well as managers in the area of environment and public health management, in order to tackle emerging problems in a comprehensive manner.

Key words: air quality, city of Novi Sad, DPSEEA model, health effects, protecting measures.

\section{Introduction}

The purpose of this article is to apply the existing scientific knowledge in the area of medical geography in the scientific description and merging of the data on the air quality and the health of the population of the city of Novi Sad. Medical geography studies the relation between the geographic environment and health, especially estimating the way natural and social environments shape the health and well-being of every individual (Cromley\&McLafferty, 2012). According to the World Health Organisation (WHO), health is not just the absence of disease, but the reflection of social and mental well-being of individuals in communities as well (World Health Organisation, 2020). The field of medical geography has developed rapidly in the last decade acknowledging that the concept of "location" plays an important role in understanding the health of individuals (Kwan, 2012, pp.891-892), while the progress in spatial modelling has eased the spatial analysis in different segments, spatial as well as temporal (Cromley\&McLafferty, 2012).

An important segment is certainly air quality as it represents an important factor in evaluating not only the environment, but the life quality of the population in any state. The relationship between air quality and human health is not only of national significance but a global issue as well. The commonly known fact is that polluted air could be spread through the atmosphere to other states, causing serious consequences on the environment and human health. Life quality, living conditions and the quality of all components and segments of the environment, air quality being one of them, represent an imperative of social development. The relationship between air quality and human health has been known through history and negative effects have already been determined. However, development and survival of society in general still lead to a continuous increase in air pollution although negative pressures have already been determined. The example is certainly the territory of Novi Sad and the entire Autonomous Province of Vojvodina.

Modelling is a case-dependent reduction (abstraction) of a real-world problem to its relevant aspects. Models reduce complex problems to 
simpler shapes, easier to manage. The skill of the model definition is in finding a formal system whose behaviour will successfully simulate the behaviour of specific aspects of the real world (Kričković, 2018, p.28).

According to a WHO working group, feasibility was pointed out as the key determinant in choosing the Environmental (public) Health Indicators (EHIs), as well as the proportion of their usability in multinational analyses which connect information collected from the environment and health systems (Matic et al, 2013, p.10). The same group of experts established a model which could be used in an Environmental Health Programme information system. The model is named by the starting letters of its structure elements (the DPSEEAmodel): $D$ - driving force; $P$ - pressure; $S$ - situation (environment status); $\mathrm{E}$ - exposure; $\quad \mathrm{E}$ - effects, and A - actions (should be conducted in a public health system) (Matić et al, 2016, p.5). Figure 1 shows the DPSEEA model, which describes how driving force, pressure, state of the environment, exposure, and effects affect actions, e.g. measures which should be conducted in order to protect human (public) health.

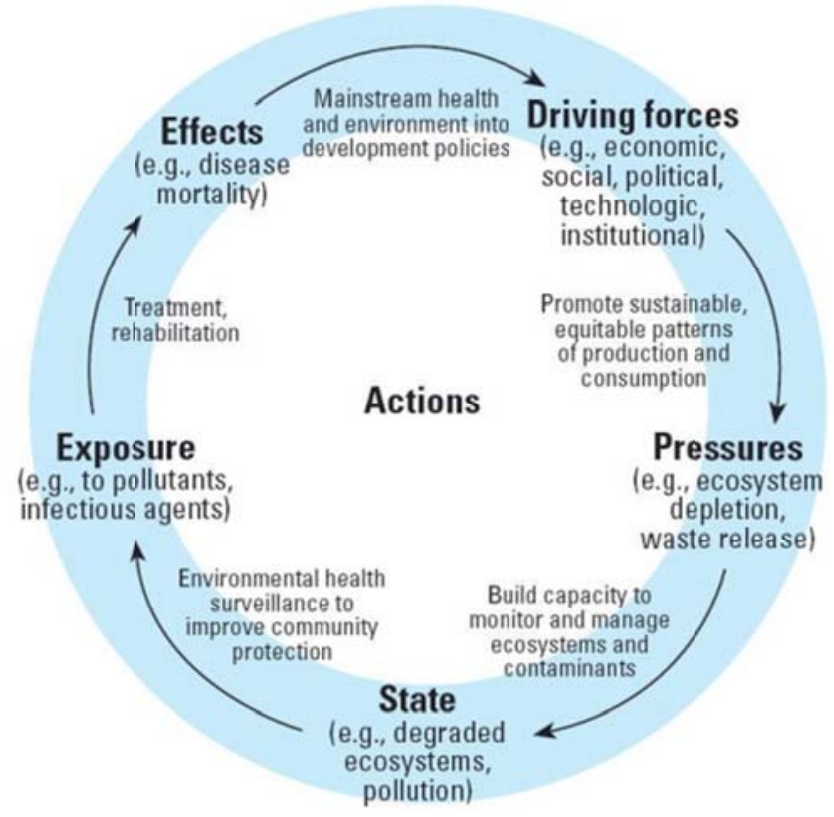

Figure 1 - DPSEEA model - framework scheme (Carneiro et al, 2006)

Puc. 1 - Модель DPSEEA - контурная диаграмма (Carneiro et al, 2006)

Слика 1 - Модел DPSEEA - оквирна шема (Carneiro et al, 2006) 


\section{Results of the research and the discussion}

If the DPSEEA model could be shown using air pollution as an example, its elements would have the following meanings:

$D=$ industry; the usage of fossil fuels in traffic; the number of kilometres per passenger in traffic;

$\mathrm{P}=$ emission of pollutants in the air;

$S=$ the concentration of pollutants in the air (emission);

$\mathrm{E}=$ population exposure to pollutants; the number of inhabitants exposed to excessive air pollution; the number of days with excessive pollution;

$E$ = quantified health effects of the polluted air; the number of respiratory and cardiovascular diseases; and

$A=$ imposed measures by the public health service in order to reduce air pollution as well as harmful effects on public health (Matic et al, 2016, p.6).

The DPSEEA model used in this article presents the biggest contaminant - industry as a driving force of air pollution in Novi Sad, while particles of sulphur and nitrogen oxides, as well as $\mathrm{PM}_{10}$ и $\mathrm{PM}_{2.5}$ particles, whose concentration is measured, present pressure on the health of the population. Pollutants from individual household heating systems during cold weather and PCDF/D particles, whose concentration is not measured, also present pressure on public health. One of big pressures on the environment, as well as on air quality, is certainly traffic i.e., the usage of fossil fuels as well as the number of kilometres per passenger in traffic. However, there is no statistical data which could show this segment; therefore, it is not considered in this work. The emission of pollutants, i.e. their average annual values, is presented as a situation. Excessive values of pollutants represent exposure to harmful effects in the environment; long-term exposure to pollutants is related to numerous chronic diseases, such as lung cancer and cerebrovascular diseases as well as children respiratory diseases. The number of patients with respiratory and cardiovascular diseases represents an effect on public heath due to exposure to pollutants. The measures imposed by public health officials represent activities conducted in the public health system in order to mitigate air pollution effects. Figure 2 shows the relationship between air quality and public (population) health in Novi Sad together with the segments of the mentioned model. 


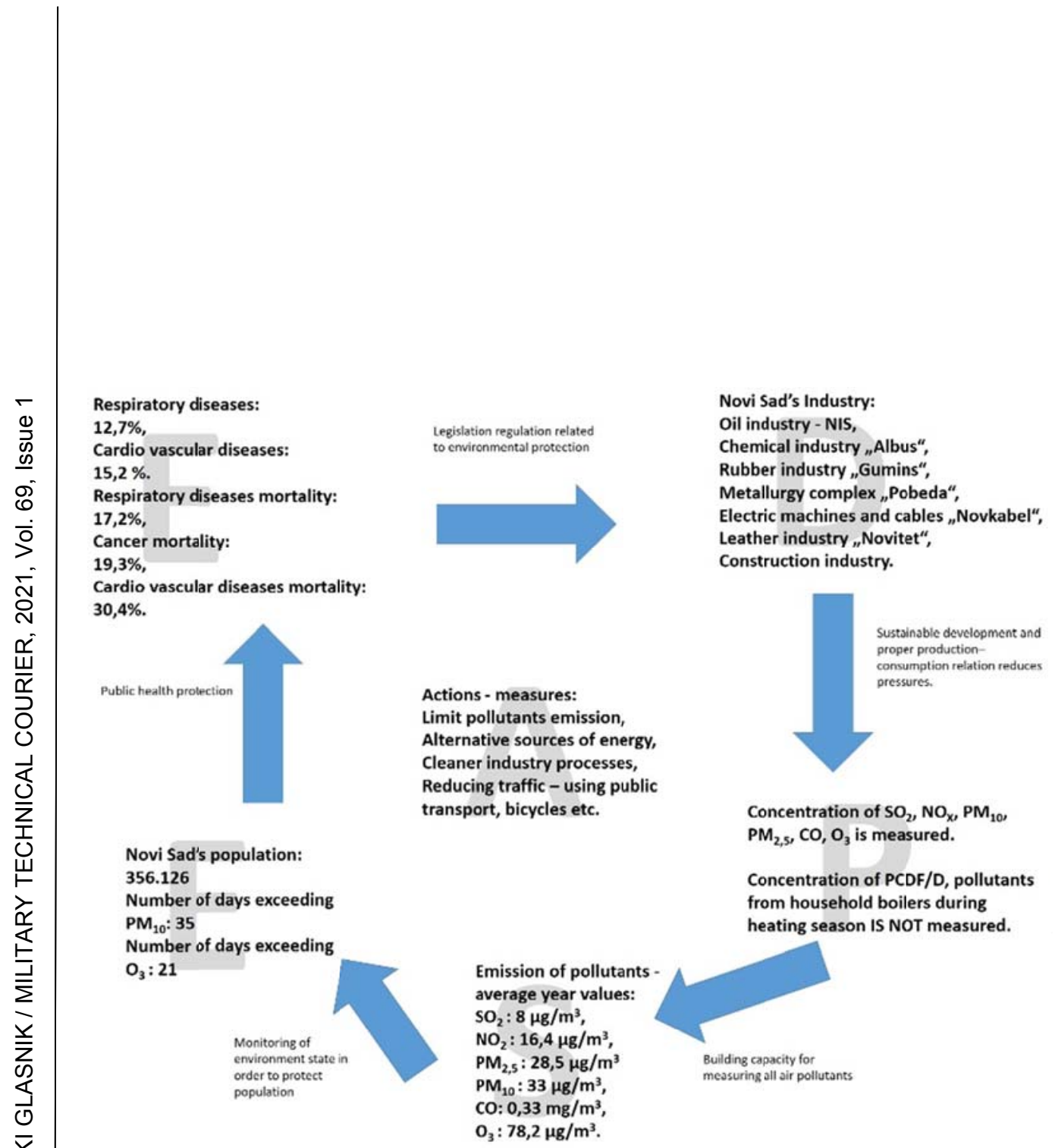

Figure 2 - Air quality - public (population) health in Novi Sad relation model Puс. 2 - Моделирование взаимосвязи между состоянием качества воздуха в Нови-Саде и здоровьем населения

Слика 2 - Моделовање везе између стања квалитета ваздуха у Новом Саду и здравља становништва

It is necessary to consider air quality as one of the factors affecting public health. In order to represent the most real situations, it is necessary to optimize air quality measures. The established automatic air quality measuring stations monitor air quality; quantity and the basic principles of the measuring stations will be described later in this article. Also, the responsibilities of national and local authorities for these stations will be specified.

According to the Development Strategy of AP Vojvodina 2014-2020, air quality in urban areas is affected by energy facilities, increasing number of vehicles, and industry. The geographic-ecological method makes it possible to conclude that air pollution in Novi Sad has its origins mostly in stationary and mobile pollution sources, and less in closed 
space. The main stationary pollution sources are the oil refinery, power plants and heating plants, chemical industry facilities, fuel combustion products in households and individual heating boiler rooms, construction industry, inappropriate storing of raw materials, landfills, etc. (Službeni list APV, 13/2014, p.150). The problem of air pollution caused by heating plants is one of the most significant environmental problems of large cities, and also that of Novi Sad, the second largest city in Serbia (Petrović, 2017, p.6).

The important sources of air pollution in Novi Sad are: NIS Gazpromneft, Chemical industry Novi Sad, Albus (detergents and cosmetics industry facility), Gumins (rubber processing, as part of chemical complex industry, developed for producing tractor tires and production of rubber-technical goods), metallurgy complex Pobeda, Novkabel (in the area of electric machines and cables), textile industry, leather industry complex Novitet, Neimar (construction industry) as well as Buducnost (Chamber of Commerce and Industry of Vojvodina, 2020).

The public enterprise Naftna Industrija Srbije, NIS - Oil Industry of Serbia from Novi Sad unites production of oil, gas and oil products engine and industry fuels, lubricants and other products based on oil. In oil refinery processes, there is significant air pollution due to the presence of easy-to-evaporate hydrocarbons and other aromatic compounds. Heating plants which use fossil fuels (lignite) and oil and oil products industry are the most significant environmental pollutants. Environmental pollution could be present in any process of electric industry: coal production (mining and surface mines), production and distribution of electric power, oil and gas sectors, starting from research and then exploitation and especially in oil processing and transport (Službeni glasnik Republike Srbije, 44/2005).

Besides being caused by old technology used in production processes, absence of exhaust filtering or poorly efficient existing filters, irrational usage of raw materials and energy, as well as poor maintenance, significant air pollution is also caused by inadequate storing and disposal of by-products. It is considered that vehicles are one of the most significant air pollutants in Novi Sad. Exhaust gasses emissions release sulphur dioxide, carbon monoxide, nitrogen oxide, ozone, and particles into the atmosphere. The data on vehicle emissions are still missing both for the city of Novi Sad and for Vojvodina province (Službeni list APV, 13/2014, p.150). 


\section{Air quality state on the territory of the city of Novi Sad and pressures on the environment}

Data on air quality and possible health effects are taken from the Report on the air quality state for 2018 , as well as from the Report on the environment for 2018 issued by the Serbian Environmental Protection Agency (SEPA) in 2019. Data on health effects are taken from the Report on Public Health for the City of Novi Sad for 2018 issued by the Institute of Public Health of Vojvodina in 2019 as well as from the Health-Statistic Yearbook for 2018 issued by the Institute of Public Health dr Milan Jovanovic Batut.

According to the Report on the environment for 2018, air quality is estimated based on available data in compliance with the regulations and recommendations from the Environment Accession Project - ENVAP. The available results from referent monitoring in national and local networks of measuring stations are used for estimating air quality in 2018. According to the Report on the air quality state for 2018, "urban agglomeration Novi Sad" covers the territory of the city of Novi Sad (Environmental Protection Agency of the Ministry of Environmental Protection of the Republic of Serbia, 2019a, p.12).

There is no national cadastral of air pollutants in urban areas in Vojvodina province. Neither there is a list of polychlorinated dibenzofurans and dioxins (PCDF/D) which are significant pollutants and whose sources are uncontrolled municipal waste incineration, metallurgy and open fires after harvesting. Monitoring of air pollutants emission from individual heating boiling rooms and domestic fireplaces in heating seasons is also missing. (Službeni list APV, 13/2014, p.150)

According to the Report on the environment for 2018, the air in Novi Sad was clean or slightly polluted. It is important to note that, in the beginning of 2018, the automatic measuring station was switched off due to big construction works. The air quality in the city of Novi Sad varies, but since 2016 it has been in the first category, i.e. clean or slightly polluted. According to the Report on the air quality state for 2018, increased content of heavy metals in analyses was from $\mathrm{PM}_{10}$ samples taken from the Novi Sad - Liman (161) measuring station, part of SEPA's national network of measuring stations. (Environmental Protection Agency of the Ministry of Environmental Protection of the Republic of Serbia, 2019b, p.28). 
Based on the statistical method, the average annual values of pollutants concentration in two measuring stations in Novi Sad are shown in Table 1 and it could be noticed that the number of days with excessive values of pollutants was 35 for $\mathrm{PM}_{10}$, and 21 for $\mathrm{O}_{3}$. Therefore, the air quality was in the First category according to the classification method. The question remains whether it is possible that only two measuring stations monitor the air quality in a city as big as Novi Sad.

\begin{tabular}{|c|c|c|c|c|c|c|c|c|c|c|c|c|c|c|}
\hline \multirow{3}{*}{ 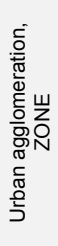 } & \multirow[b]{3}{*}{ Station } & \multirow{3}{*}{ 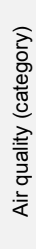 } & \multicolumn{12}{|c|}{ Average annual concentration of air pollutants } \\
\hline & & & \multicolumn{2}{|c|}{$\mathrm{SO}_{2}$} & \multicolumn{2}{|c|}{$\mathrm{NO}_{2}$} & \multicolumn{2}{|r|}{$\mathrm{PM}_{10}$} & \multirow{2}{*}{$\begin{array}{l}\mathrm{PM}_{2,5} \\
\mu \mathrm{g} / \mathrm{m}^{3}\end{array}$} & \multirow{2}{*}{$\begin{array}{l}\mathrm{C}_{6} \mathrm{H}_{6} \\
\mu \mathrm{g} / \mathrm{m}^{3}\end{array}$} & \multicolumn{2}{|c|}{$\mathrm{CO}$} & \multicolumn{2}{|r|}{$\mathrm{O}_{3}$} \\
\hline & & & $\mu \mathrm{g} / \mathrm{m}^{3}$ & $\begin{array}{c}\text { Number } \\
\text { of } \\
\text { days> } \\
125 \\
\mu \mathrm{g} / \mathrm{m}^{3}\end{array}$ & $\mu \mathrm{g} / \mathrm{m}^{3}$ & $\begin{array}{c}\text { Number } \\
\text { of } \\
\text { days }>85 \\
\mu \mathrm{g} / \mathrm{m}^{3}\end{array}$ & $\mu \mathrm{g} / \mathrm{m}^{3}$ & $\begin{array}{c}\text { Number of } \\
\text { days }>50 \mu \mathrm{g} / \mathrm{m}^{3}\end{array}$ & & & $\mathrm{mg} / \mathrm{m}^{3}$ & $\begin{array}{c}\text { Number } \\
\text { of } \\
\text { days }>5 \\
\mathrm{mg} / \mathrm{m}^{3}\end{array}$ & $\mu \mathrm{g} / \mathrm{m}^{3}$ & $\begin{array}{c}\text { Number } \\
\text { of } \\
\text { days }>120 \\
\mu \mathrm{g} / \mathrm{m}^{3}\end{array}$ \\
\hline \multirow{2}{*}{$\begin{array}{l}\text { Novi } \\
\text { Sad }\end{array}$} & $\begin{array}{l}\text { Novi } \\
\text { Sad } \\
\text { Liman }\end{array}$ & 1 & 8.00 & 0 & 16.4 & 0 & 33.0 & 35 & & & 0.33 & 0 & 78.2 & 21 \\
\hline & $\begin{array}{l}\text { Novi } \\
\text { Sad } \\
\text { Sangaj } \\
\text { (L) }\end{array}$ & I & 8.00 & 0 & & & & & & & & & & \\
\hline
\end{tabular}

Табле 1 - Average annual concentration of air pollutants (Environmental Protection Agency of the Ministry of Environmental Protection of the Republic of Serbia, 2019b, p.42), adjusted

Таблица 1 - Годовая концентрация загрязняющих веществ в воздухе (Environmental Protection Agency of the Ministry of Environmental Protection of the Republic of Serbia, 2019b, p.42), адаптировано

Табела 1 - Годишња концентрација загађујућих материја у ваздуху (Environmental Protection Agency of the Ministry of Environmental Protection of the Republic of Serbia, 2019b, р.42), прилагођено

A combination of methods, i.e. the classification method and the analysis of the Report on the air quality state for 2018, and the comparison of the air quality categories for the last 9 years made it possible to conclude that in 2010 and 2011 the air quality in Novi Sad was in the third category.

During 2012 to 2014, the air quality was in the first category; in 2015, it was in the second category, while in the period from 2016 to 2018, the air quality was in the first category. When the air quality categories are concerned, it is important to notice that there are specific warnings and recommendations to the population for certain categories of air quality. 
Increased concentrations of pollutants during winter are not surprising regarding increased usage of coal, fuel oil or gas for heating, i.e. heating plants (Institute of Public Health of Vojvodina, 2019a, p.7). The assumption is that the increased concentration of $\mathrm{PM}_{10}$ and $\mathrm{CO}_{2}$ particles during the winter period is caused by the usage of these fossil fuels. This relation between pollutants and weather parameters, not just during the heating season but during the whole year as well, points out to a possible source of pollution in Novi Sad, i.e. to a possible influence of weather on air quality.

When possible sources of pollutants related to urban areas (traffic/household heating) are considered, the results show that traffic has a more significant influence on air quality during the summer period. This implies a bigger influence of household heating and heating plants during winter.

Also, according to the same study, air quality is more related to weather parameters during the summer period, when humidity is lower and there are conditions for spreading air pollutants characteristic for urban areas whilst during winter, due to higher air pressure, there are conditions for an increased number of $\mathrm{PM}_{10}$ particles (Institute of Public Health of Vojvodina, 2019a, p.9).

The cartographic method, Figure 3 and Figure 4, shows the spatial distribution of $\mathrm{SO}_{x}$ and $\mathrm{NO}_{x}$ emissions by municipalities and quadrants of $25 \times 25$ kilometres. The data used for this model are taken from the National Register of Pollution Sources (NRIZ) as an information subsystem of the Environmental Information System of the Republic of Serbia. According to Figure 3, the average annual $\mathrm{SO}_{\mathrm{x}}$ emission for Novi Sad is in the range from 1 to 100 tons per year, and according to Figure 4 the average annual $\mathrm{NO}_{x}$ emission is in the range from 100 to 1,000 tons per year. 


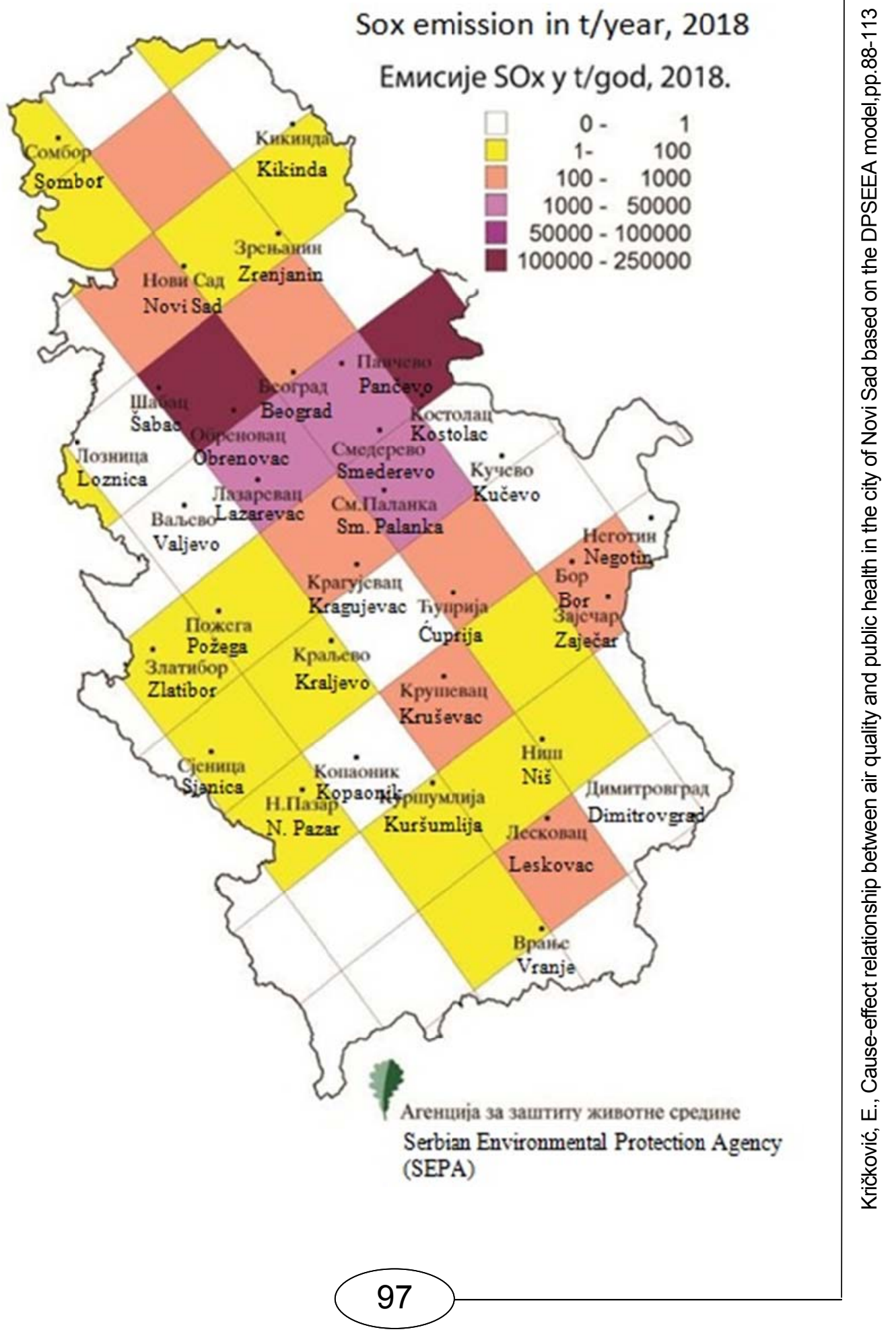




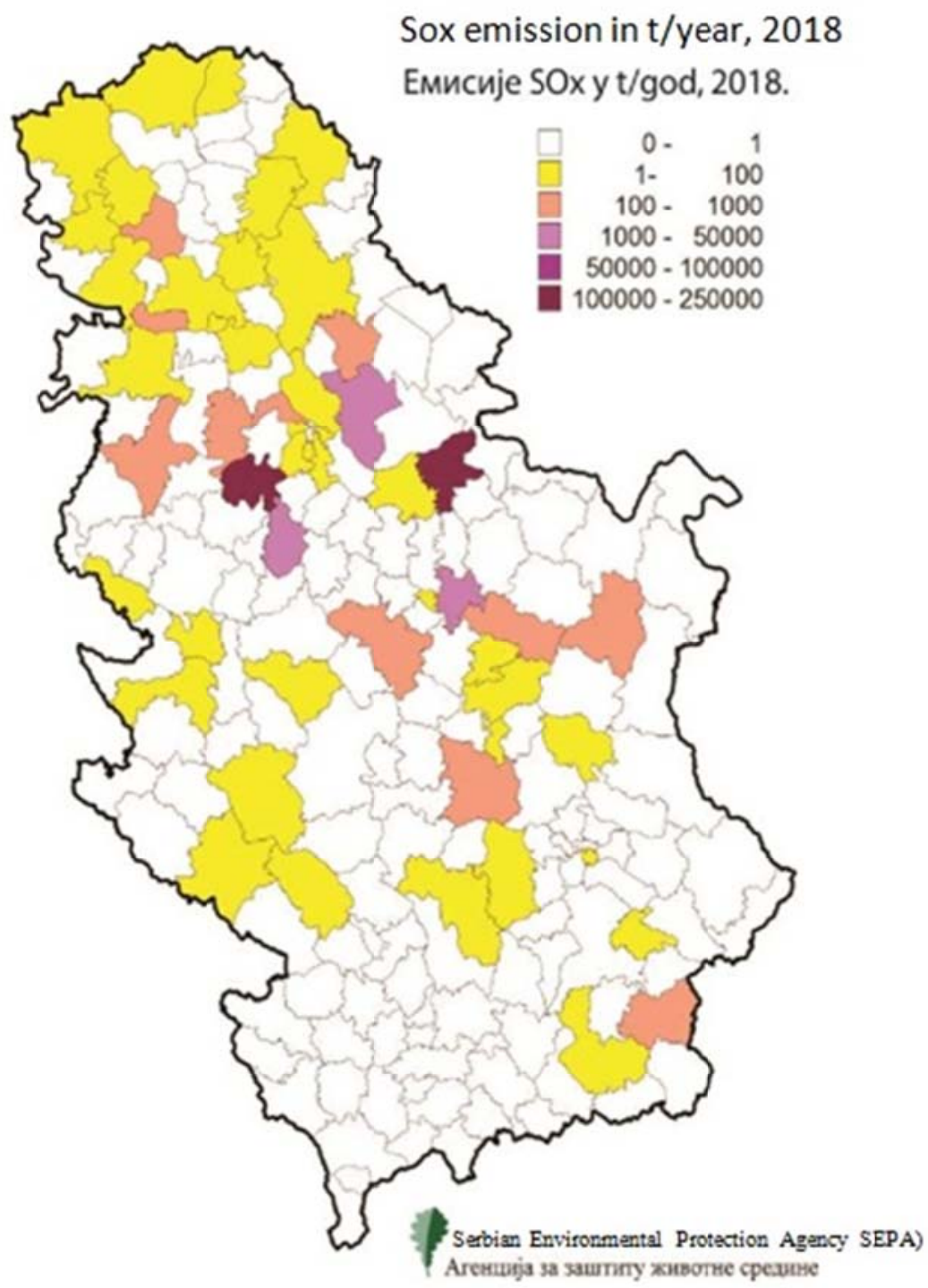

Figure 3 - Spatial distribution of sulphide oxides by municipalities in Serbia (Environmental Protection Agency of the Ministry of Environmental Protection of the Republic of Serbia, 2019b, p.19), adjusted

Рисунок 3 - Пространственное распределение выбросов оксида серы по муниципалитетам в Сербии (Environmental Protection Agency of the Ministry of Environmental Protection of the Republic of Serbia, 2019b, p.19), адаптировано Слика 3 - Просторна расподела емисија сумпорних оксида по опитинама у Србији (Environmental Protection Agency of the Ministry of Environmental Protection of the Republic of Serbia, 2019b, p.19), прилагођено 


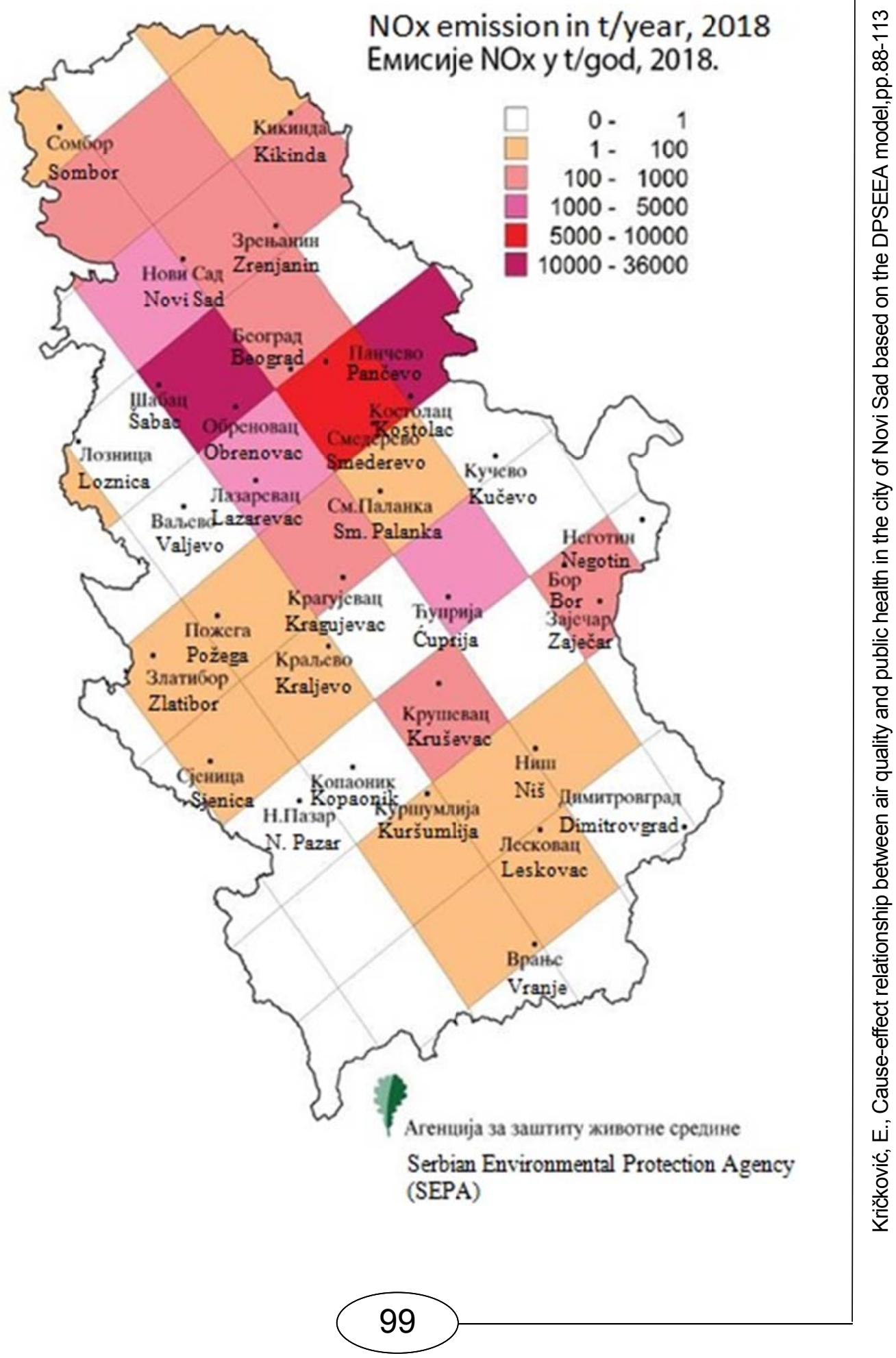




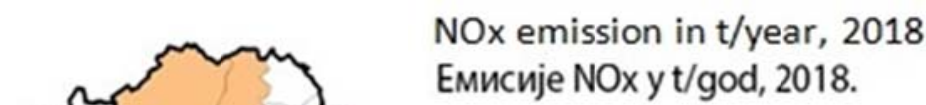

Емисије NOx y t/god, 2018.

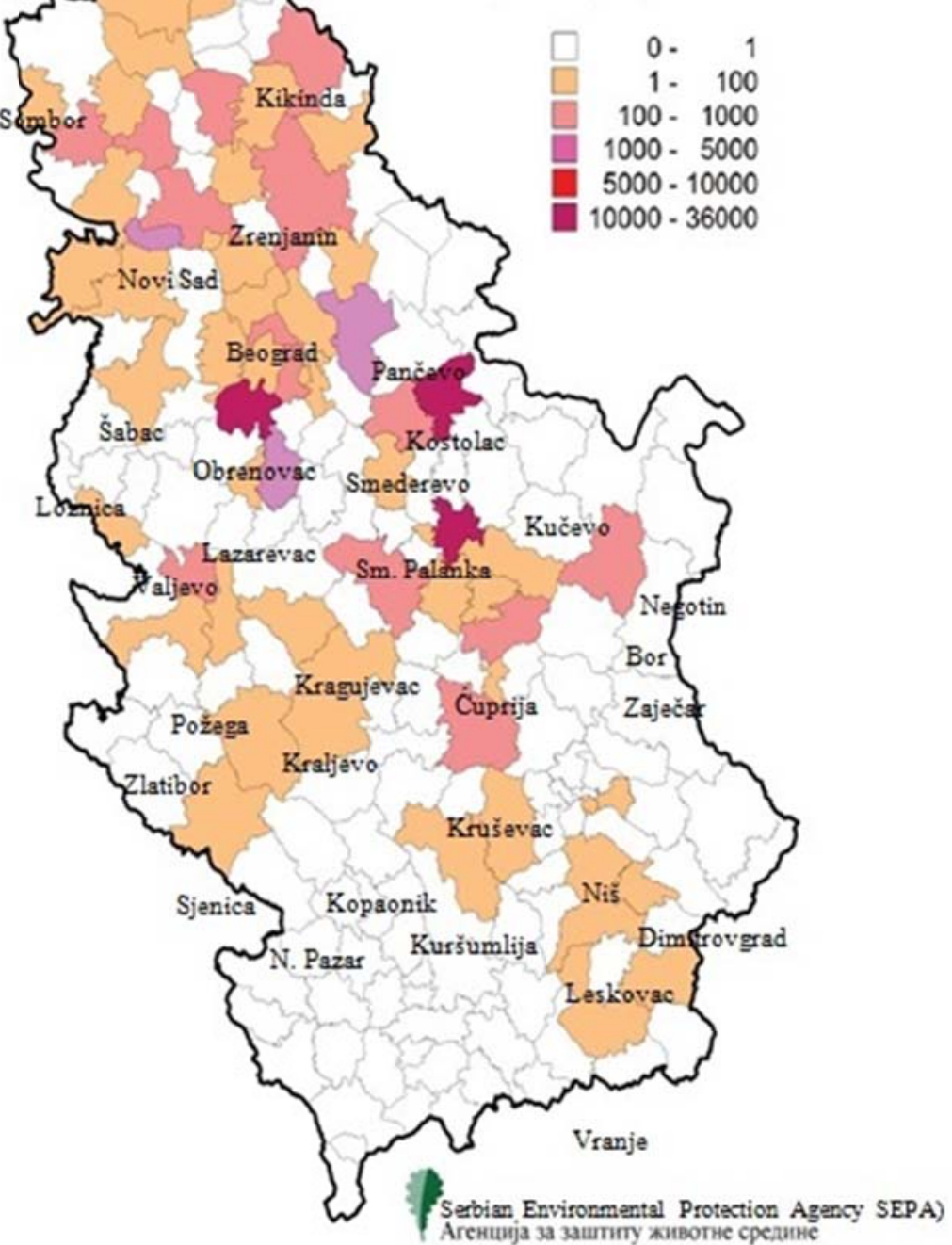

Figure 4 - Spatial distribution of nitrogen oxides by municipalities in Serbia (Environmental Protection Agency of the Ministry of Environmental Protection of the Republic of Serbia, 2019b, p.19), adjusted

Pис. 4 - Пространственное распределение выбросов оксида азота по муниципалитетам в Сербии (Environmental Protection Agency of the Ministry of Environmental Protection of the Republic of Serbia, 2019b, p.19), адаптировано Слика 4 - Просторна расподела емисија азотних оксида по општинама у Србији (Environmental Protection Agency of the Ministry of Environmental Protection of the Republic of Serbia, 2019b, p.19), прилагођено 
Novi Sad's population exposure to variable air quality

According to the Statistical Office of the Republic of Serbia in 2017, Novi Sad had the population of 356,126 inhabitants, which is 55,000 more inhabitants than in the census of 2002. From the Report on Population Health in Novi Sad for 2018, it is clear that excessive values of the following pollutants were determined in Novi Sad: $\mathrm{PM}_{2,5}$ suspended particles exceeded the limit values by $12 \%$ (the limit value is $25 \mu \mathrm{g} / \mathrm{m}^{3}$ ), $\mathrm{PM}_{2,5}$ suspended particles exceeded the permissible values by $8 \%$ (the permissible value is $26.4 \mu \mathrm{g} / \mathrm{m}^{3}$ ) and the concentration of benzo(a)pyrene in $\mathrm{PM}_{10}$ suspended particles exceeded the prescribed values in $69 \%$ (the prescribed value is $1 \mathrm{ng} / \mathrm{m}^{3}$ ) (Institute of Public Health of Vojvodina, 2019b, p.110).

The values exceeding the prescribed concentrations of air pollutants in Novi Sad during one year period are presented using the cartographic method in Figure 5. Urban areas are shown in black, while suburban areas are shown in purple. The City's Direction for Environment's data is used for this method and provided by the Institute of Public Health of Vojvodina.

According to the same report, exceedances of the limit values of air pollutants are determined daily: limit/permissible concentration value $\left(50 / 50 \mu \mathrm{g} / \mathrm{m}^{3}\right)$ for $\mathrm{PM}_{10}$ suspended particles during 14 days, which is $25 \%$ of 112 controlled days. Exceeded values were in the range from 52 to 88 $\mathrm{\mu g} / \mathrm{m}^{3}$; daily limit/permissible value $\left(85 / 97 \mu \mathrm{g} / \mathrm{m}^{3}\right)$ for nitrogen oxide during 10 days, limit values $(2.77 \%)$ and 7 days, permissible values $(1.94 \%)$ out of 361 controlled days (Institute of Public Health of Vojvodina, 2019b, p.111).

The concentrations of nitrogen-dioxide exceeding daily limits were in the range from 85.5 to $134 \mu \mathrm{g} / \mathrm{m}^{3}$; the concentrations of ozone exceeded the prescribed value $\left(120 \mu \mathrm{g} / \mathrm{m}^{3}\right)$ during five days out of 350 controlled days.

These exceeded values were in the range from 121.5 to $205 \mu \mathrm{g} / \mathrm{m}^{3}$. According to the Report on Public Health in Novi Sad for 2018, due to national regulation, daily concentrations of $\mathrm{PM}_{2.5}$ particles are analysed only annually. 
Figure 5 - Values exceeding the prescribed concentrations of air pollutants in Novi Sad during one year period (Institute of Public Health of Vojvodina, 2019b, p.110), adjusted

Puс. 5 - Ежегодное превышение предписанных концентраций загрязняющих веществ в воздухе города Нови-Сад (Institute of Public Health of Vojvodina, 2019b, p.110), адаптировано

Слика 5 - Прекорачење прописаних концентрација загађујућих материја из ваздуха града Новог Сада на годишњем нивоу(Institute of Public Health of Vojvodina, 2019b, р.110), прилагођено

The cartographic methodis used in Figure 6 to show exceedances of daily concentrations of air pollutants in Novi Sad during 2018. Urban areas are marked in black, and suburban areas are marked in purple. This method used the data from the City's Direction for Environment, provided by the Institute of Public Health. 


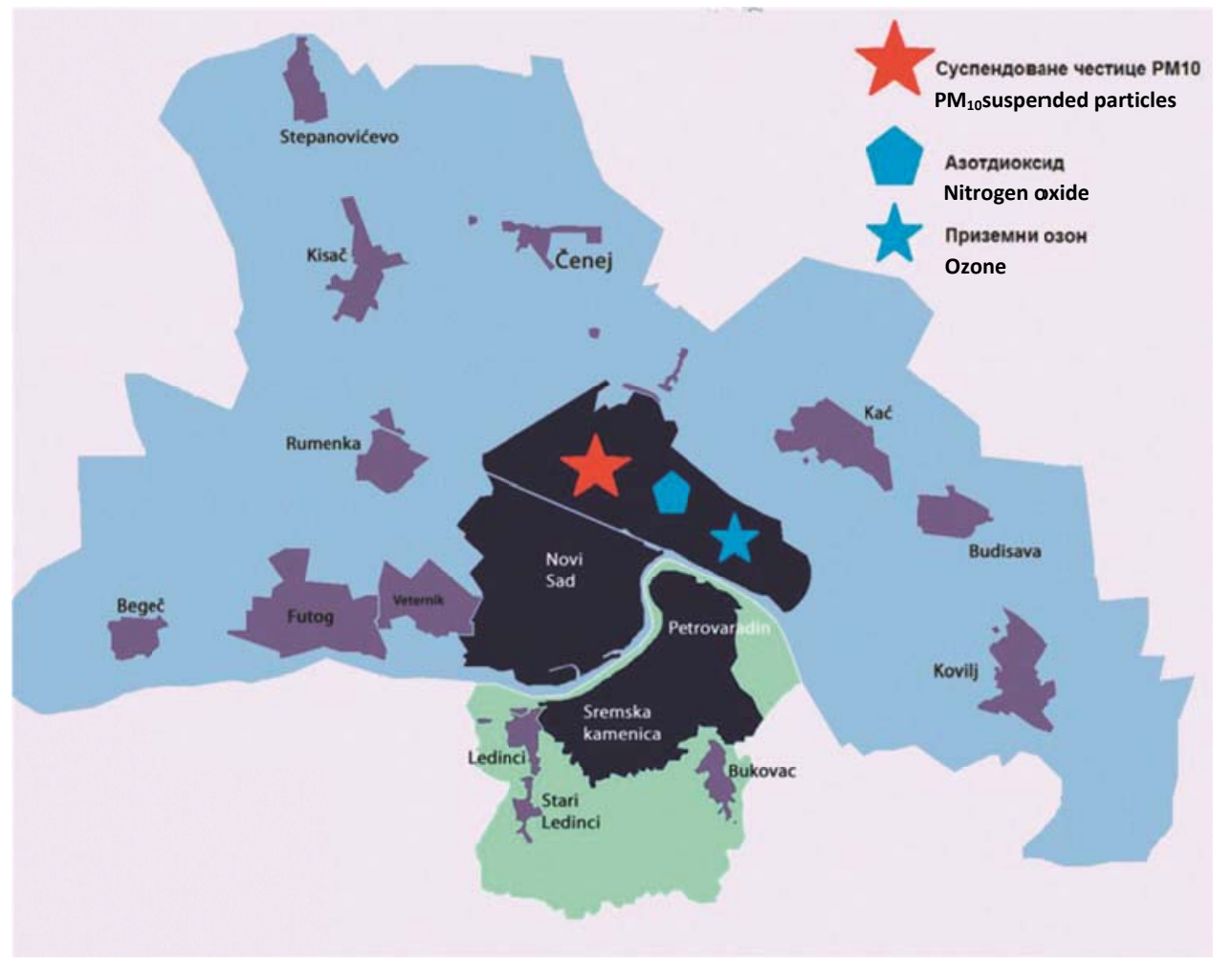

Figure 6 - Exceedances of the prescribed concentrations of air pollutants in Novi Sad on a daily basis during 2018 (Institute of Public Health of Vojvodina, 2019b, p.111), adjusted Puc. 6 - Превышение предписанных концентраций загрязняющих веществ в воздухе города Нови-Сад на ежедневной основе в течение 2018 года (Institute of Public Health of Vojvodina, 2019b, p.111), адаптировано

Слика 6 - Прекорачење прописаних концентрација загађујуће материје из ваздуха града Новог Сада на дневном нивоу током 2018. године (Institute of Public Health of Vojvodina, 2019b, p.111), прилагођено

\section{Effects of degraded air quality on the population health in} Novi Sad

Medical disorders caused by air pollution (inner and external) in urban and rural areas in both developed and undeveloped regions of the world could be due to acute or chronic exposure (Pirić et al, 2018, p.29).

Based on the medical-geographic description method and the analysis of the Report on Public Health in Novi Sad for 2018, the leading causes of deaths are chronic non-infectious diseases (cardio vascular and malignant diseases, respiratory and digestive system diseases, diseases related to endocrine system, nutrition and metabolism) which 
make $86.2 \%$ of mortality. The most significant public health problem of Novi Sad is chronic non-infectious diseases (Institute of Public Health of Vojvodina, 2019b, p.8). According to the same report, almost half of the morbidity rates outside of the Novi Sad health system are due to diseases related to the cardiovascular system, the respiratory system, skin, muscles, bones and the digestive system. The leading causes of diseases among children in Novi Sad are diseases related to the respiratory system (Institute of Public Health of Vojvodina, 2019b, p.8).

The total registered morbidity in primary care in Novi Sad during 2018 was 368,023 cases, with the leading diseases related to the cardiovascular system (15.2\%) and the respiratory system $(12.7 \%)$ (Institute of Public Health of Vojvodina, 2019b, p.36). Occupational medicine provides primary health care for working population. This service registered 122,764 cases of morbidity. The leading causes of diseases were diseases related to the respiratory system $(16.9 \%)$ and the cardiovascular system (10.4\%) (Institute of Public Health of Vojvodina, 2019b, p.37). The pre-school health services registered 105,630 cases of diseases. The majority of those were diseases related to the respiratory system (49\%) and the upper tract (17.1\%) (Institute of Public Health of Vojvodina, 2019b, p.38). The total registered morbidity in school health services was 81,337 cases. The leading causes were diseases related to the respiratory system (40.8\%) (Institute of Public Health of Vojvodina, 2019b, p.39). The leading death causes of hospitalized patients in Novi Sad in 2018 were diseases related to the cardiovascular system with $30.4 \%$ in the total number of deaths. Tumours were in the second place $(19.3 \%)$ while diseases relatted to the respiratory system were in the third place $(17.2 \%)$ (Institute of Public Health of Vojvodina, 2019b, p.42).

The pollution caused by traffic reduces the efficiency of the defence mechanisms of the respiratory system and increases sensitivity to respiratory infections. The presence of certain concentrations of nitrogen oxides, carbon-monoxides and benzenes in the air lead to risks of cough, bronchitis and asthma, especially with children. The most harmful to health are emissions of suspended particles with a diameter smaller than 2.5 micrometres $\left(\mathrm{PM}_{2.5}\right)$. The medical geography forecast method is helpful in concluding that these particles can go deep into the lungs causing acute inflammatory processes. Long-term exposure to these particles is related to various chronic diseases in adults, including coronary artery disease, lung cancer and cerebrovascular diseases, as well as children respiratory diseases (Obradović-Arsić, 2014). 
According to the "Identification of Environmental Risk Factors Important for the Prevention of Chronic Obstructive Pulmonary Disease among the Population of the City of Novi Sad" study conducted by the Institute of Public Health of Vojvodina, during the summer period women are more sensitive to pollutant exposure. Likewise, it is established that beside heavy metals, spores of rust fungi and pollen as immunogenic substances are often found in $\mathrm{PM}_{10}$ particles. It is well known that these particles worsen asthma symptoms. Due to these facts, it is clear that summer periods present risks for potential interactions of air pollutants with allergens. These results could be explained by the fact that children are longer and more frequently outside than the adults, as well as by mutual influence of weather factors and PM10 particles, especially in the mentioned period (if relative humidity is lower, the concentration of $\mathrm{PM}_{10}$ particles is higher). According to the same study, epidemiologic research indicates a strong relation between $\mathrm{PM}_{10}$ and $\mathrm{PM}_{2.5}$ particles and respiratory morbidity and mortality (Institute of Public Health of Vojvodina, 2019a, p.12).

\section{Protection measures}

Numerous health effects present in the subject territory certainly indicate the current state of air quality. Air pollution reduction and the limitation of pollutant emissions should be of greater importance in the future, as well as the promotion of alternative sources of energy, clean industry, the principle of "pollutant paying", traffic reduction, bicycle use, etc.

Services in charge of monitoring the air quality in the territory of the city of Novi Sad are obliged to continually monitor air quality and send data to the competent institution. This institution combines and unites data from different areas of Serbia and its name is the Serbian Environmental Protection Agency (SEPA).

The network of automated monitoring of the air quality in Vojvodina province is presented in Figure 7 with the cartographic method. It shows that there are three measuring stations in the territory of Novi Sad - two are established by SEPA and one by the Provincial Secretariat for Urban Planning and Environmental Protection (PSUPEP). These three automated measuring stations continually monitor pollutants along with the basic weather parameters and send hourly average measured concentrations using ADSL/GPRS in real time, for further processing in the central data processing systems.

By the EU Exchange of Information Decisions (Eol), air quality data are defined together with the process of informing the public as well as 
the exchange of data with other member states (Larssen et al, 1999, p.4). In accordance with the Eol classification, these three measuring stations are located in:

- Novi Sad - Rumenacka; this station measures the influence of traffic in an urban area with residential/commercial characteristics and SEPA is in charge of it;

- Novi Sad - Liman; this static station is in an urban area with potential agglomeration, with SEPA being in charge of it; and

- Novi Sad - Sangaj; this static station in a suburban area with residential characteristics measures the influence of specific industrial pollution, with PSUPEP being in charge of it (PSUPEP. More information at http://www.ekourbapv.vojvodina.gov.rs).

The analysis-synthesis method shows (Figure 7 ) that the agglomeration of Novi Sad is covered with only three permanent air quality measuring stations. For a city of the size of Novi Sad with the population of over 350,000 , it can be said these are good locations, but still inadequate for a real situation regarding the air quality in Novi Sad.

According to the "Identification of environmental risk factors important for the prevention of chronic obstructive pulmonary disease among the population of the City of Novi Sad" study, conducted by the Institute of Public Health of Vojvodina, air quality measuring is significant in the efforts for preventing obstructive pulmonary disease, as the air quality is one of the factors for the mentioned disease. Every air quality assessment related to population diseases, e.g. assessment of the environmental factors influencing population health, is very important for the policy of improving the protection of population health and managing air quality. According to the same study, the following is necessary:

- Institutional networking and stronger capacity for air quality monitoring with a view to assessing population exposure;

- Assessing the influence of air quality on public health using models with a wider spectrum of air pollutants and environmental factors, during a multi-year period;

- Improving the information system (health statistics and environmental data networking);

- Informing the public using the Air Quality Index; and

- Increasing the level of ecological awareness and education through establishing special programs. 


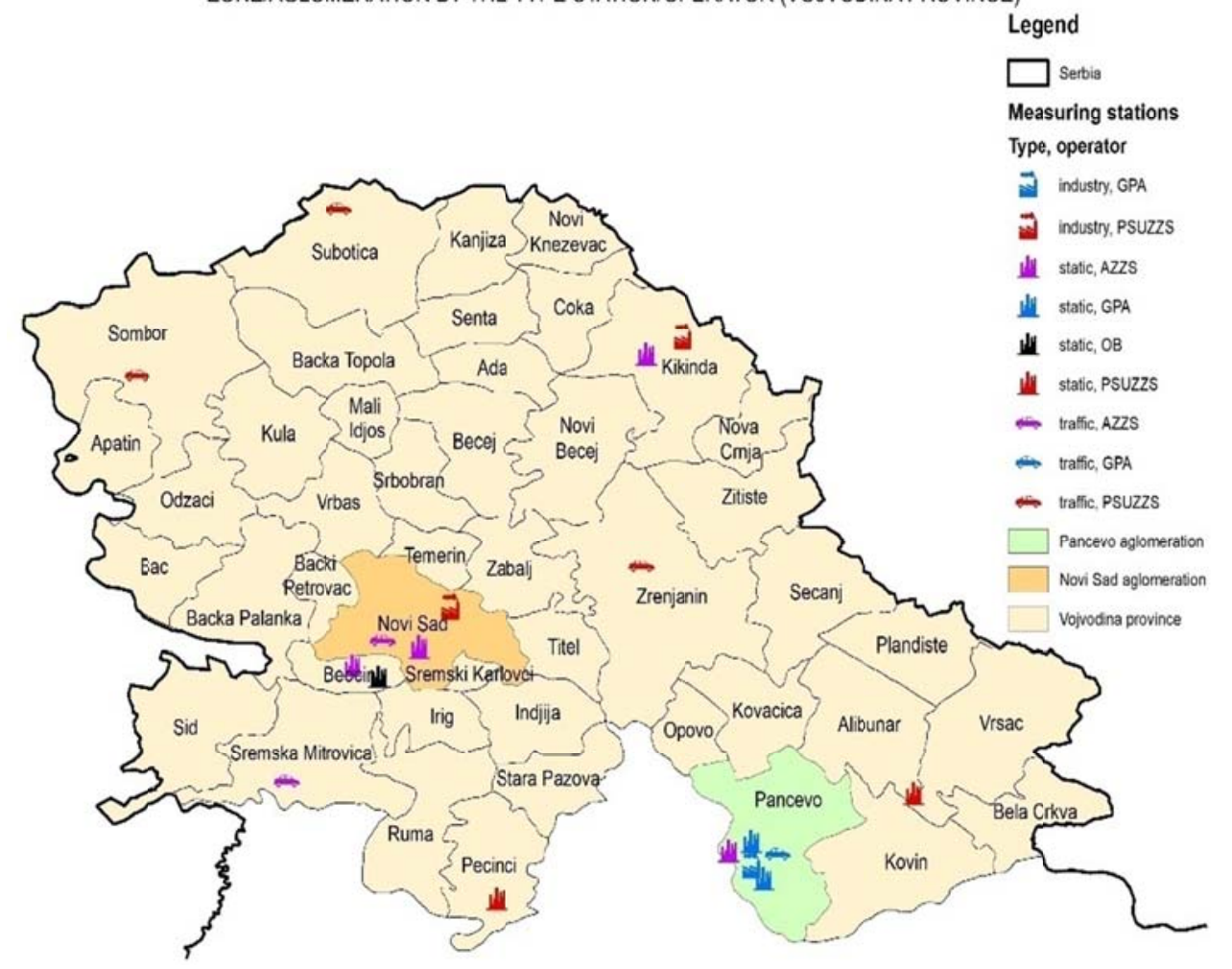

Figure 7 - Network of automated air monitoring in Vojvodina province; by the type of the station and its operator (Pokrajinski sekretarijat za urbanizam i zaštitu životne sredine, 2020), adjusted

Puc. 7 - Сеть автоматического мониторинга атмосфрерного воздуха в АПВ; по типу станции и оператору (Pokrajinski sekretarijat za urbanizam i zaštitu životne sredine, 2020), адаптировано

Слика 7 - Мрежа аутоматског мониторинга амбијенталног ваздуха у АПВ, по mипу станице и оператеру (Pokrajinski sekretarijat za urbanizam i zaštitu životne sredine, 2020), прилагођено

If the Air Quality Index shows unhealthy air, it is necessary to adhere to proper warnings and recommendations. Special attention and limitations for outdoor activities should be directed to specific population categories, such as children and the elderly.

According to the Report on Air Quality State for 2018, weather parameters affect the maximum pollen concentration in the air, notably air temperature, humidity, and precipitation. Besides weather conditions, 
proper and timely trimming of grass and weeds has a positive effect in reducing pollen concentrations in the air. It is necessary to increase controlled extermination of aggressive weeds such as common ragweed (Ambrosia artemisiifolia) as a reliable measure in reducing the concentration of this strongest allergen in the air (Environmental Protection Agency of the Ministry of Environmental Protection of the Republic of Serbia, 2019b).

\section{Conclusion}

In order to fulfil the WHO's aim - health for everyone, the progress should not be focused only on reducing cases of diseases related to air quality, but it is necessary to prevent them and define measures for the prevention of air pollution in the whole territory as well.

It is important to emphasize differences in individual immune systems as well as in the quantity and types of harmful agents. People also differ in body response to an infectious dose, depending on their predispositions (age, general state of health, and other factors). It is necessary to properly manage health risks through defining the prevention measures and the measures for population protection. In case of negative effects and emerging diseases related to air pollution, it is necessary to adopt the measures for suppressing diseases in the territory in question (Kričković et al, 2019, pp.61-76).

According to the $\mathrm{WHO}$, a public health care system, aiming at reducing the risk of emerging diseases and promoting good relations in the community, needs to monitor many social and environmental factors (World Health Organisation, 2020). The DPSEEA model has a wide use in all segments of environmental and medical geography. Therefore, it is possible to use this model for the identification of potential hazardous risks in the environment alongside with health side effects in order to protect public health and avoid negative effects.

In this article, the cause-effect relationship between polluted air and public health is presented through driving forces, pressures on the environment, state of the air quality, population exposure to pollution, the effects of pollution to public and individual health, as well as actions which should be applied in order to reduce air pollution and increase the health of Novi Sad's population.

Identifying industry as one of the driving forces and pressures affecting the environment is only the first step in order to assess air quality. The absence of statistical data for the usage of fossil fuels in traffic as well as for the number of miles per inhabitant is compensated 
by measuring pollutants from traffic, so the average particle concentrations per year are mentioned, as well as the number of days with exceeded concentrations of pollutants such as particles. Diseases morbidity and mortality among Novi Sad's population related to air pollution are also shown. Finally, preventive and protection measures are presented as actions which should be adopted in order to improve the health of Novi Sad's population.

In accordance with the Health Environment Indicators in the Republic of Serbia in 2015 report, the DPSEEA model starts from the basics because it is primarily focused on population health and the environment, as the driving forces are a product of pressures themselves (mechanism of harmful effects). This model is beneficial since it comprises a wide spectrum of potential forces (harmful effects) and the ensuing public actions, bringing together professionals, field workers, laboratory work force as well as managers in the field of environment managing and public health in order to deal with emerging problems in a comprehensive manner.

\section{References}

Carneiro, F.F., Oliveira, M.L.C., Netto, G.F., Galvão, L.A.C., Cancio, J.A., Bonini, E.M., Corvalan, C.F.\& the Participants in the International Symposium on the Development of Indicators for Environmental Health Integrated Management. 2006. Meeting Report: Development of Environmental Health Indicators in Brazil and Other Countries in the Americas. Environmental Health Perspectives, 114(9), pp.1307-A556. Available at: https://doi.org/10.1289/ehp.8486.

-Chamber of Commerce and Industry of Vojvodina. 2020. Industrija Vojvodine [online]. Available at: https://www.pkv.rs/2004/09/28/industrijavojvodine/ (in Serbian) [Accessed: 1 November 2020].

Cromley, E.K. \& McLafferty, S.L. 2012. GIS and Public Health, Second Edition. New York: Guilford Press. ISBN: 9781609187507.

-Environmental Protection Agency of the Ministry of Environmental Protection of the Republic of Serbia (SEPA). 2019a. Izveštaj o stanju životne sredine za 2018. godinu. Belgrade: Environmental Protection Agency of the Ministry of Environmental Protection of the Republic of Serbia (SEPA) [online]. Available at: http://www.sepa.gov.rs/download/lzvestaj2018.pdf (in Serbian) [Accessed: 1 November 2020].

-Environmental Protection Agency of the Ministry of Environmental Protection of the Republic of Serbia (SEPA). 2019b.Godišnji izveštaj o stanju kvaliteta vazduha u Republici Srbiji za 2018. Belgrade: Environmental Protection Agency of the Ministry of Environmental Protection of the Republic of Serbia (SEPA) [online]. Available at: http://www.sepa.gov.rs/download/izv/Vazduh2018_final.pdf (in Serbian) [Accessed: 1 November 2020]. 
-Institute of Public Health of Vojvodina. 2019a. Prepoznavanje faktora rizika iz životne sredine značajnih za prevenciju hronične opstruktivne bolesti pluća među stanovništvom grada Novog Sada. Novi Sad: Institute of Public Health of Vojvodina [online]. Available at: http://izjzv.org.rs/uploads/ddbd4a24-356a-dab0-c031e3e5b1102a0e/Prilog\%20lzvestaju\%20Projekta\%20zdravstvo\%20HOBP\%202018. pdf (in Serbian)[Accessed: 1 November 2020].

-Institute of Public Health of Vojvodina. 2019b. Zdravstveno stanje stanovništva grada Novog Sada 2018. Godine [online]. Available at: http://izjzv.org.rs/?Ing=lat\&link=4-21 (in Serbian) [Accessed: 1 April 2020].

Kričković, Z. 2018. Modelovanje geoprostornih bazapodataka za potrebe istraživanja uticaja geografskih faktora na zdravlje ljudi. MA thesis. Belgrade: University of Belgrade - Faculty of Geography (in Serbian).

Kričković, E., Živanović, M. \& Kričković, Z. 2019. Rural area population health ware as key factor of Serbian village development. Zbornik radova Geografski fakultet Univerziteta u Beogradu, 67-1, pp.61-76. Available at: https://doi.org/10.5937/zrgfub1901061K.

Kwan, M-P. 2012. Geographies of health. Annals of the Association of American Geographers, 102(5), pp.891-892. Available at: https://doi.org/10.1080/00045608.2012.687348.

Larssen, S., Sluyter, R. \& Helmis, C. 1999. Criteria for EUROAIRNET The EEA Air Quality Monitoring and Information Network, Technical Report No. 12. Copenhagen: European Environment Agency[online]. Availlable at: https://www.eea.europa.eu/publications/TEC12 [Accessed: 1 April 2020].

Matić, B., Jovanović, D., Dejanović, S. \& Rakić, U. 2013. Zdravstveni indikatori životne sredine u Republici Srbiji u 2012. godini. Belgrade: Institute of Public Health of Serbia "Dr Milan Jovanović Batut" [online]. Available at: http://www.batut.org.rs/download/izvestaji/ZivotnaSredinaENHIS2012.pdf (in Serbian) [Accessed: 1 November 2020].

Matić, B., Dejanović, S., Knežević, T., Živadinović, D.\& Rakić, U. 2016. Zdravstveni indikatori životne sredine u Republici Srbiji u 2015. godini. Belgrade: Institute of Public Health of Serbia "Dr Milan Jovanović Batut"[online]. Available at: http://www.batut.org.rs/download/izvestaji/higijena/Zdravstveni\%20indikatori\%20zi votne\%20sredine\%202015.pdf (in Serbian). [Accessed: 1 November 2020].

Obradović-Arsić, D. 2014. Medicinsko-geografski faktori u planiranju $i$ zaštiti prostora. Belgrade: University of Belgrade - Faculty of Geography (in Serbian). ISBN: 978-86-6283-017-3.

Petrović, J. 2017. Ekološki aspekti rada termoenergetskih postrojenja u Novom Sadu-aerozagađenje. Ph.D. thesis. Sremska Kamenica: University Educons - Faculty of Environmental Protection (in Serbian).

Pirić, S., Aleksopulos, H. \& Ilić, V. 2018. Air pollution as a risk factor for the health of the population of the City of Kragujevac. Sestrinska reč, 21(76) (in Serbian). Available at: https://doi.org/10.5937/SestRec1876028P.

-Pokrajinski sekretarijat za urbanizam i zaštitu životne sredine. 2020. Automatski monitoring kvaliteta ambijentalnog vazduha.Mreža automatskog monitoringa ambijentalnog vazduha u APV, po tipu stanice $i$ operateru [online]. 
Available

at:

http://www.ekourbapv.vojvodina.gov.rs/wpcontent/uploads/2018/09/mreza-automatskog-monitoringa-ambijentalnogvazduha-u-APV.jpg (in Serbian) [Accessed: 1 November 2020].

-Službeni glasnik Republike Srbije. 44/2005. Strategija razvoja energetike Republike Srbije do 2015. godine. Belgrade: JP „Službeni glasnik“ (in Serbian) [online]. Available at: https://www.mre.gov.rs/doc/efikasnostizvori/01\%20Strategija\%20razvoja\%20energetike\%20Republike\%20Srbije\%20d ०\%202015\%20godine.pdf (in Serbian) [Accessed: 1 November 2020].

-Službeni list APV. 13/2014. Program razvoja AP Vojvodine 2014-2020. Novi Sad: Republic of Serbia, Autonomous province of Vojvodina, Provincial Secretariat for Education, Regulations, Administration and National Minorities National Communities [online]. Available at: http://www.puma.vojvodina.gov.rs/sllist.php (in Serbian) [Accessed: 1 November 2020].

-World Health Organisation (WHO). 2020. Health Workforce [online]. Available at: http://www.who.int/gho/health_workforce/physicians_density/en/ [Accessed: 1 November 2020].

ПРИЧИННО-СЛЕДСТВЕННАЯ СВЯЗЬ МЕЖДУ СОСТОЯНИЕМ КАЧЕСТВА ВОЗДУХА В НОВИ-САДЕ И ЗДОРОВЬЕМ НАСЕЛЕНИЯ С ИСПОЛЬЗОВАНИЕМ МОДЕЛИ DРSЕЕ

Эмина С. Кричкович

Белградский университет, географический фракультет, г. Белград, Республика Сербия

РУБРИКА ГРНТИ: 39.00.00 ГЕОГРАФИЯ:

39.25.00 Медицинская география;

39.25.15 Условия среды и здоровье населения,

39.25.19 География болезней и их возбудителей,

39.25.23 Медико-географическая характеристика отдельных территорий, здравоохранение в отдельных странах

ВИД СТАТЬИ: оригинальная научная статья

\section{Резюме:}

Введение/цель: Исследовательской проблемой данной статьи является здоровье населения города Нови-Сад. Предметом исследования является состояние качества воздуха. В статье представлена взаимосвязь между этими сегментами с помощьюмодели DPSEEA. Цель данной статьи заключается в привлечении внимания кнеобходимости сохранения здоровья населения Нови-Сада. Социальная цель исследования должна обеспечить предоставление населению Нови-Сада научных данныхо влиянии качества воздуха, а на основании этих данных должны быть предприняты надлежащие меры для смягчения негативного воздействия на здоровье населения. Основная 


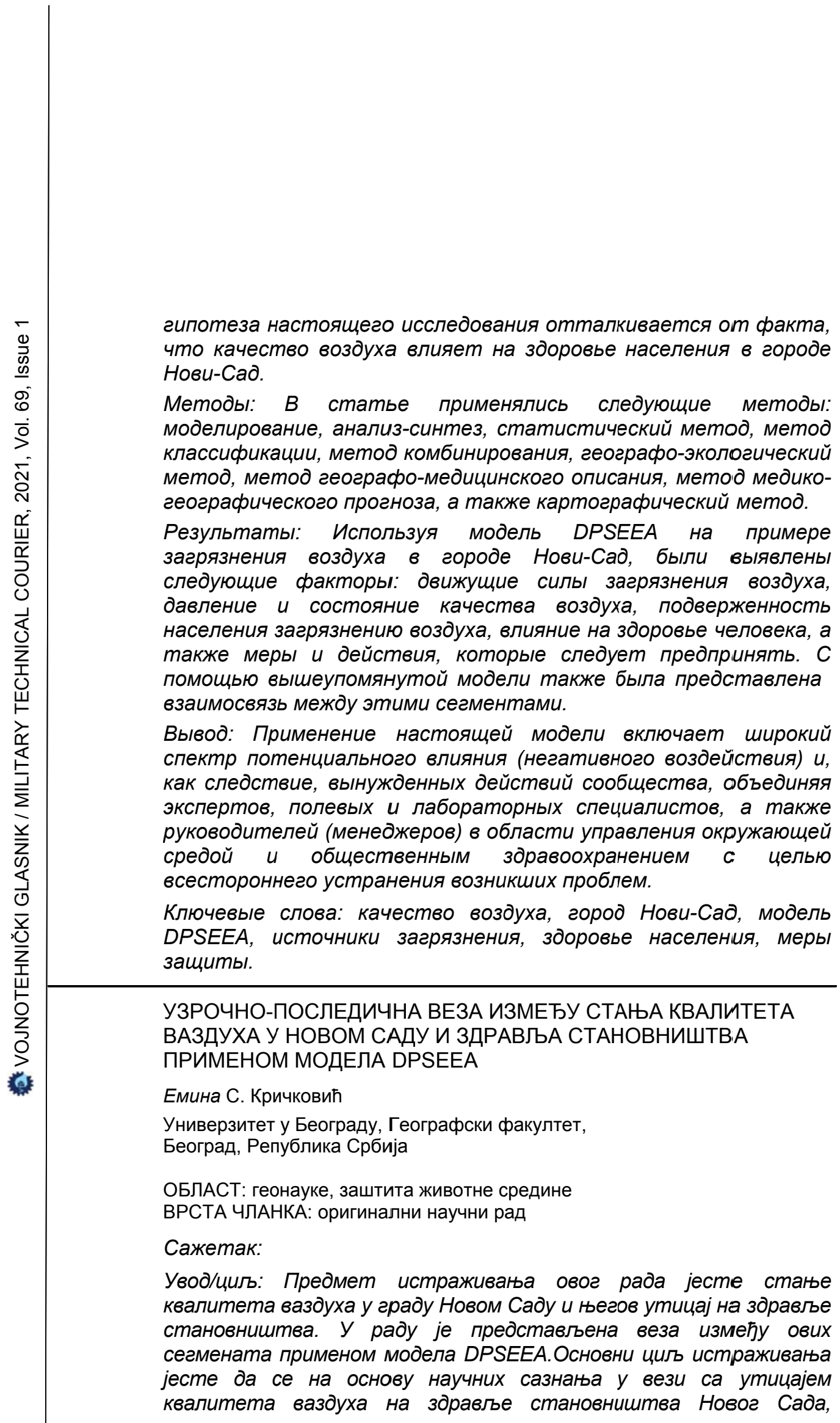


предузму одређене мере ради отклањања негативних последица по здравље. Основна хипотеза истраживања полази од чињенице да квалитет ваздуха утиче на здравље становништва Новог Cada.

Meтоде: у истраживању су коришћене следеће методе истраживања: метод моделовања, метод анализа-синтеза, статистички метод, метод класификације, комбиновани метод, географоско-еколошки метод, метод медицинско-географоског описивања, метод медицинско-географрске прогнозе, као и картографрски метод.

Резултати: Применом модела DPSEEA на примеру загађења ваздуха на територији Новог Сада идентификовани су покретачи загађења ваздуха, притисци и стање квалитета ваздуха, изложеност популације загађењу, здравствени ефректи, као и мере заштите и акције које би требало спровести. Такође, применом наведеног модела представљена је веза између наведених сегмената.

Закључак: Примена овог модела обухвата широки спектар потенцијалних сила (итетних дејстава) и акција заједнице које из њих произилазе, доводећи у везу професионалне кадрове, људе са терена и из лабораторија, као и руководиоце (меначере) из области управљања животном средином и јавног здравља, са циљем да се на свеобухватнији начин баве решавањем наведених проблема.

Кључне речи: квалитет ваздуха, град Нови Сад, модел DPSEEA, извори загађења, здравље становништва, мере заштите.

Paperreceivedon/Дата получения работы/ Датумпријемачланка: 08.11.2020.

Manuscriptcorrectionssubmittedon / Дата получения исправленной версии работы/ Датумдостављањаисправкирукописа: 23.12.2020.

Paperacceptedfor publishingon / Дата окончательного согласования работы/ Датумконачногприхватањачланказаобјављивање: 25.12.2020.

(c) 2021 The Author. Published by Vojnotehnički glasnik / Military Technical Courier (www.vtg.mod.gov.rs, втг.мо.упр.срб). This article is an open access article distributed under the terms and conditions of the Creative Commons Attribution license (http://creativecommons.org/licenses/by/3.0/rs/).

(c) 2021Автор. Опубликованов «Военно-техническийвестник / Vojnotehničkiglasnik / MilitaryTechnical Courier» (www.vtg.mod.gov.rs, втг.мо.упр.срб). Данная статья в открытом доступе и распространяется в соответствии с лицензией «CreativeCommons» (http://creativecommons.org/licenses/by/3.0/rs/).

(c) 2021 Аутор. Објавио Војнотехнички гласник / Vojnotehničkiglasnik / MilitaryTechnicalCourier (www.vtg.mod.gov.rs, втг.мо.упр.срб). Ово је чланак отвореног приступа и дистрибуира се у складу са CreativeCommons лиценцом (http://creativecommons.org/licenses/by/3.0/rs/).

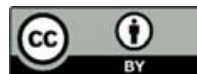

